\title{
Population abundance and growth rate of western gray whales Eschrichtius robustus
}

\author{
Amanda L. Bradford ${ }^{1, *}$, David W. Weller ${ }^{2}$, Paul R. Wade ${ }^{3}$, Alexander M. Burdin ${ }^{4,5,6}$, \\ Robert L. Brownell Jr. ${ }^{7}$ \\ ${ }^{1}$ School of Aquatic and Fishery Sciences, University of Washington, Box 355020, Seattle, Washington 98195-5020, USA \\ ${ }^{2}$ Southwest Fisheries Science Center, NMFS, NOAA, 8604 La Jolla Shores Drive, La Jolla, California 92037-0271, USA \\ ${ }^{3}$ National Marine Mammal Laboratory, Alaska Fisheries Science Center, NMFS, NOAA, 7600 Sand Point Way NE, Seattle, \\ Washington 98115-6349, USA \\ ${ }^{4}$ Kamchatka Branch of Pacific Institute of Geography, Far East Branch of the Russian Academy of Sciences, Pr. Rybakov, \\ 19-a, Petropavlovsk-Kamchtsky 683024, Russia \\ ${ }^{5}$ Alaska SeaLife Center, 301 Railway Avenue, Seward, Alaska 99664, USA \\ ${ }^{6}$ University of Alaska Fairbanks, PO Box 757500, Fairbanks, Alaska 99775, USA \\ ${ }^{7}$ Southwest Fisheries Science Center, NMFS, NOAA, 1352 Lighthouse Avenue, Pacific Grove, California 93950, USA
}

\begin{abstract}
The western population of gray whales Eschrichtius robustus is one of the most endangered whale populations in the world. Recent studies of this population off the northeastern coast of Sakhalin Island, Russia, have produced a photographic dataset that was utilized for the first markrecapture assessment of western gray whale abundance. Given encounter histories of 129 individually identified whales spanning 25 monthly capture occasions from 1997 to 2003, a closed capture estimator was employed to estimate the number of individuals using the study area in each year. Temporary emigration probabilities were then applied to the closed capture estimates to enumerate the total population size of whales off northeastern Sakhalin Island. Total abundances from 1997 to 2003 were estimated as $64 \pm 5.1$ (SE), 55 to $75(95 \% \mathrm{CI}) ; 75 \pm 4.9,66$ to $85 ; 86 \pm 3.1,80$ to $93 ; 77 \pm 4.7$, 68 to $87 ; 91 \pm 3.4,84$ to $98 ; 98 \pm 4.1,90$ to 106 ; and $99 \pm 4.9,90$ to 109 , respectively. These abundance estimates, particularly the last values in the series, most likely approximate the size of the entire western gray whale population. For comparison to the trend in the abundance estimates, life history data were used to estimate the growth rate of the population. Depending on the range of potential fecundity values incorporated, the resulting growth rate estimates indicate an annual population increase that is between 2.5 and $3.2 \%$. The extremely small population size and slow rate of increase documented here further highlight concern about the viability of this critically endangered population.
\end{abstract}

KEY WORDS: Abundance · Mark-recapture - Temporary emigration - Population growth rate • Simulation approach · Photo-identification · Western gray whale · Sakhalin Island, Russia

\section{INTRODUCTION}

Gray whales Eschrichtius robustus occur along the eastern and western coastlines of the North Pacific as 2 geographically isolated populations (Rice \& Wolman 1971) and are referred to as the eastern and western populations (Weller et al. 2002b). Eastern gray whales feed during summer months primarily in the Bering and
Chukchi Seas after migrating along the western coast of North America from winter breeding grounds off Baja California (Pike 1962). Western gray whales migrate along the eastern coast of northern Asia to summer feeding grounds in the Okhotsk Sea (Berzin 1990). The location of the winter breeding grounds for this population is unknown, but is thought to be along the coast of southern China (Wang 1984, Omura 1988, Kato \& Kasuya 
2002, Weller et al. 2002b). In addition to a geographic separation, recent molecular comparisons based on differences in haplotypic frequencies confirm that the eastern and western gray whale populations are genetically differentiated at the population level (LeDuc et al. 2002).

Both eastern and western gray whales were commercially hunted during the 19th and 20th centuries, which led to dramatic reductions in the size of each population. After more than half a century of international protection, the eastern gray whale population has recovered to near pre-exploitation numbers (Reilly 1992) and may be equilibrating at its current carrying capacity (Wade 2002). Recent abundance estimates of eastern gray whales, based on shore-based counts of migrating individuals, indicate that the population numbers on the order of 20000 whales (Rugh et al. 2005). Having been subjected to a prolonged period of population removals and delayed protection measures, the western gray whale population was depleted to such low numbers that it was proposed to be extinct during the 1970s (Bowen 1974). Western gray whales exist today as a remnant population (Brownell \& Chun 1977, Blokhin et al. 1985, Weller et al. 1999), which is listed as 'Critically Endangered' by the International Union for Conservation of Nature (IUCN) (HiltonTaylor 2000, Weller et al. 2002b). Considered to be one of the world's most endangered baleen whale populations (Clapham et al. 1999), the viability of the western gray whale population remains uncertain (Weller et al. 2002b, Reeves et al. 2005).

Concern regarding the status of western gray whales relative to increasing anthropogenic activity throughout their range (i.e. coastal waters of Russia, Japan, the Korean peninsula, and China) led to the initiation of the first research program to evaluate their population biology. This ongoing study, a collaboration between Russian and US scientists, has been in progress since 1997 on the primary western gray whale feeding ground, which is located off the northeastern coast of Sakhalin Island, Russia, in the Okhotsk Sea, and is considered to provide access to most, if not all, of the western gray whale population (see 'Discussion: Application of estimates'). Gray whales are individually identifiable by natural pigmentation patterns, allowing individuals to be monitored using photographs. This technique, known as photo-identification, is a primary research method of the Russia-US western gray whale research program (Weller et al. 1999). The utility of photo-identification in cetacean population studies has been well established (see Hammond et al. 1990 for a review), particularly in terms of its link to markrecapture parameter estimation (e.g. Hammond 1986, Buckland 1990). Mark-recapture techniques were successfully applied to the western gray whale photoidentification dataset in order to estimate survival probabilities of these whales from 1997 to 2003 (Bradford et al. 2006).

While there is compelling evidence to suggest that the western gray whale population is indeed small in size (Weller et al. 2002b), a series of quantitative abundance estimates has not yet been published. The primary goal of the present set of analyses was to estimate the annual abundance of western gray whales using mark-recapture methodology. As detailed in 'Discussion: Abundance estimates', given the extensive overlap with the analytical framework used to estimate western gray whale survival (Bradford et al. 2006), the abundance estimates reported here will likewise span the years 1997 to 2003. Maintaining this time period also allows the estimates herein to serve as a baseline for planned updated mark-recapture population assessments of western gray whales, as well as for recently initiated modeling-based assessments (e.g. Cooke et al. 2007).

A secondary objective of the analyses was to estimate the population growth rate of western gray whales from 1997 to 2003 using available life history information and a simulation approach. Such an estimate can be compared to the trend in the mark-recapture abundance estimates, while also providing a more targeted measure of the population rate of increase, which is needed to make inferences about the status of the population. As with the series of abundance estimates, a quantitative estimate of western gray whale population growth rate has not been published to date.

\section{MATERIALS AND METHODS}

Photo-identification. Photo-identification surveys of western gray whales were conducted during summer months between 1997 and 2003 off northeastern Sakhalin Island, Russia, in a nearshore region approximately $70 \mathrm{~km}$ long and $5 \mathrm{~km}$ wide near the entrance to Piltun Lagoon (Fig. 1). Recent aerial surveys have indicated that the photo-identification study area includes the majority of whales feeding near Piltun Lagoon (e.g. Weller et al. 2002c, Blokhin et al. 2004). Therefore, the study area can alternatively be referred to as the Piltun feeding ground. Identical methodology was employed during each survey, with the primary objective of encountering and photographically identifying as many whales as possible given fuel supply, weather conditions, and whale availability. Specific details about the study area and the photo-identification data collection and analysis protocols are provided in Weller et al. (1999).

A total of 259 photo-identification surveys, conducted during $25 \mathrm{mo}$, produced a catalog of 129 individually identified whales. A summary of annual sur- 


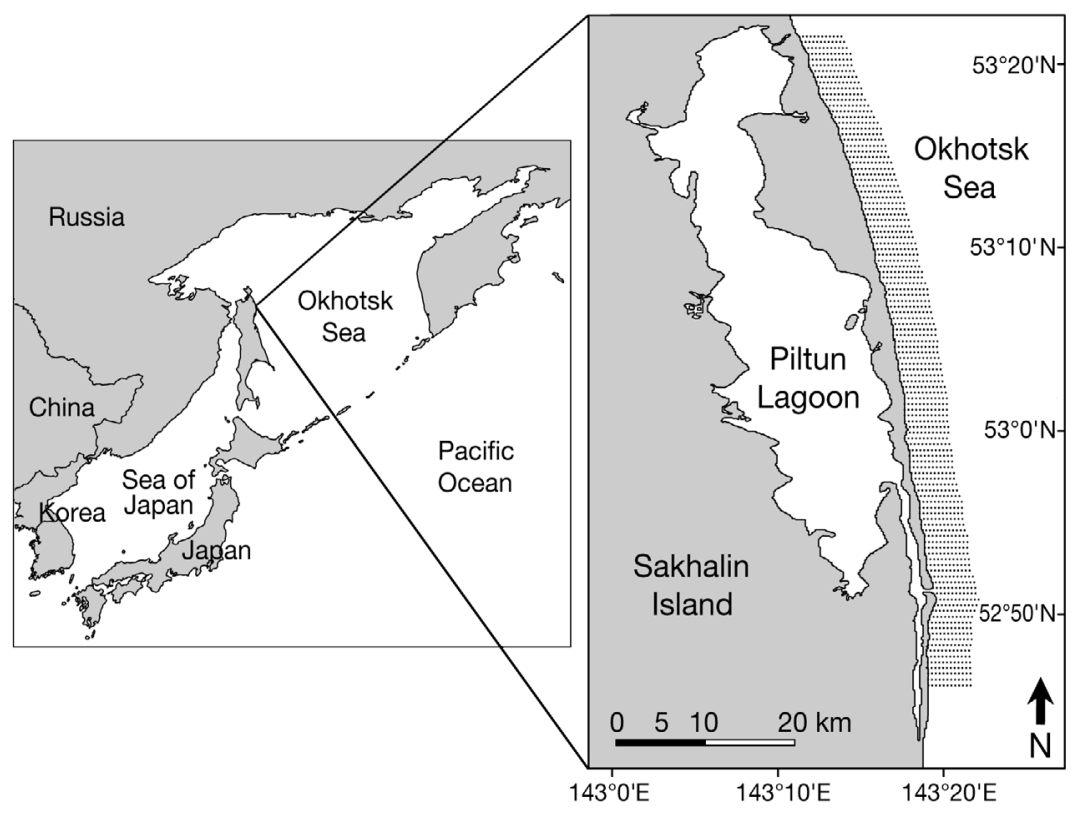

Fig. 1. Eschrichtius robustus. Photo-identification study area (dotted lines) on the western gray whale feeding ground off Piltun Lagoon, Sakhalin Island, Russia, in the Okhotsk Sea

vey effort and whale photo-identification is shown in Table 1. Encounter histories for these 129 whales represent the dataset analyzed here.

Abundance estimation. Mark-recapture models to estimate abundance can either be closed or open in construct. Estimating abundance using closed population models instead of open population models allows for (1) the incorporation of heterogeneity in estimates of capture probability, and (2) the estimation of population size in each of the closed primary sampling periods (see Kendall \& Pollock 1992, for summary). Thus, given the extensive annual survey effort for western gray whales reported here, it is preferable to estimate the abundance of this population using a closed population model. Clearly, a main assumption of such a model is that that the population of study is closed to additions (through recruitment or immigration) and deletions (through mortality or emigration) (Seber 1982). The assumption that the western gray whale population is closed to births and deaths within each primary sampling period (i.e. field season) is reasonable. However, photo-identification results have demonstrated that whales do immigrate to and emigrate from the study area during each field season (Weller et al. 1999, 2002a,b, 2003). Kendall (1999) found that random movement in and out of a study area does not bias estimates of closed population models, although precision is decreased. A more significant bias results when individuals are absent from the study area during the entire primary sampling period (i.e. temporary emigration), as these individuals will be excluded from ensuing population estimates (Kendall et al. 1997). Photo-identification findings have suggested that some whales can be absent from the study area during any given field season (Weller et al. 1999, 2002a,b, 2003), although it is also possible that some whales present on the Piltun feeding ground during any given year may not be encountered and photographed.

A mark-recapture analysis of the 1997 to 2003 western gray whale photographic dataset was performed using Pollock's robust design model (Pollock 1982, Kendall \& Pollock 1992, Kendall \& Nichols 1995, Kendall et al. 1995, 1997), combining the CormackJolly-Seber (CJS) open recapture model (Cormack 1964, Jolly 1965, Seber 1965) and Huggins' closed capture estimator (Huggins 1989, 1991), to estimate survival, temporary emigration, and capture probabilities

Table 1. Eschrictius robustus. Summary of annual survey effort and western gray whale photo-identification from 1997 to 2003. Note that the number of whales identified annually includes resightings of individuals from previous years, while the photoidentification catalog size indicates the cumulative number of whales identified, excluding resightings)

\begin{tabular}{|lcccccc|}
\hline Year & $\begin{array}{c}\text { Sampling period } \\
(\mathrm{mm} / \mathrm{dd}-\mathrm{mm} / \mathrm{dd})\end{array}$ & $\begin{array}{c}\text { No. } \\
\text { of months }\end{array}$ & $\begin{array}{c}\text { No. } \\
\text { of surveys }\end{array}$ & $\begin{array}{c}\text { No. of } \\
\text { whales identified }\end{array}$ & $\begin{array}{c}\text { Calves/non-calves } \\
\text { identified }\end{array}$ & $\begin{array}{c}\text { Photo-identification } \\
\text { catalog size }\end{array}$ \\
\hline 1997 & $07 / 09-09 / 08$ & 3 & 22 & 47 & $2 / 45$ & 47 \\
1998 & $07 / 06-09 / 29$ & 3 & 35 & 54 & $8 / 46$ & 67 \\
1999 & $06 / 29-10 / 13$ & 5 & 56 & 69 & $3 / 66$ & 95 \\
2000 & $06 / 25-09 / 16$ & 4 & 40 & 58 & $6 / 55$ & 103 \\
2001 & $06 / 25-09 / 25$ & 4 & 48 & 72 & $7 / 69$ & 116 \\
2002 & $07 / 01-09 / 25$ & 3 & 36 & 22 & $11 / 64$ & 129 \\
2003 & $07 / 15-09 / 13$ & 3 & 259 & & $40 / 89$ & 129 \\
Overall & & 25 & & & & \\
\hline
\end{tabular}


of this population (Bradford et al. 2006). Specifically, random temporary emigration was assumed to be constant, group varying (between older and younger whales), time varying, or group and time varying. The effects of various combinations of time, survey effort, and an individual residency covariate were examined in models of capture probability. The individual covariate served as an index of the duration of residency of an individual whale in the study area, and was intended to reduce individual heterogeneity in capture probability (Bradford et al. 2006). Model selection was performed using Akaike's Information Criterion (Akaike 1973) corrected for small sample size (AICC) (Hurvich \& Tsai 1989). Models incorporating higher temporary emigration probabilities for younger whales and individual heterogeneity in residency patterns provided better fits to the data. In particular, the highest AICc-weighted model allowed temporary emigration to differ between whales first sighted as calves for $3 \mathrm{yr}$ post-weaning and older whales (i.e. between whales $<4$ yr old and whales $\geq 4 \mathrm{yr}$ old), and capture probability to vary by secondary sampling period (i.e. month) and residency.

Yearly abundance estimates can be derived from the closed capture estimator used in the previously described Bradford et al. (2006) western gray whale mark-recapture analysis. However, these estimates would reflect only the portion of the population associated with the study area during each primary sampling period and not account for temporary emigrants. Kendall et al. (1997) described that, in the presence of random temporary emigration:

$$
N_{i}=\left(1-\gamma_{i}\right) N_{i}^{\circ}
$$

where $N_{i}$ is the number of individuals in a population exposed to sampling efforts during primary sample $i_{r} \gamma_{i}$ is the probability of being unavailable for capture in primary sample $i$ (i.e. temporary emigration), and $N_{i}^{\circ}$ is the number of individuals in a population during primary sample $i$, such that:

$$
N_{i}^{\mathrm{o}}=\frac{1}{\left(1-\gamma_{i}\right)} N_{i}
$$

Thus, the 1997 to 2003 western gray whale temporary emigration probabilities estimated using Pollock's robust design model (Bradford et al. 2006) can be used in conjunction with closed capture estimates of population size in the study area and the relationship expressed in Eq. (2) to produce estimates of total population abundance. In this case, 'population abundance' is defined as the number of whales associated with the Piltun feeding ground during the course of the study $\left(N_{i}^{\circ}\right)$, as opposed to the number of whales using the feeding ground during a single field season $\left(N_{i}\right)$.

However, the highest AICc-weighted model in the Bradford et al. (2006) analysis estimated 2 temporary emigration probabilities, one for whales $\geq 4$ yr old and one for whales $<4 \mathrm{yr}$ old, that were constant for each group during the study period $\left(\gamma_{g}\right)$.

Therefore, estimating the annual number of individuals associated with the study area for each of the 2 groups was necessary for the present analysis. For each of the 2 groups, Huggins' closed capture estimator (Huggins 1989, 1991) was fitted to the western gray whale encounter histories using maximum likelihood parameter estimation as implemented in Program MARK (White \& Burnham 1999). Maintaining the structure of the 1997 to 2003 robust design model (Bradford et al. 2006), the field seasons in each of the $7 \mathrm{yr}$ of the study (1997 to 2003) were considered the primary sampling periods, while the months within a field season $(3,3,5,4,4,3$, and 3 in each year, respectively) were considered the secondary sampling periods.

The following parameters were estimated: $N_{g i}=$ number of individuals in group $g$ exposed to sampling efforts during primary period $i$, where $g$ is either $\geq 4 \mathrm{yr}$ old or $<4$ yr old and $i=1997,1998 \ldots, 2003$; and $p_{h i j}=$ probability of individual whale $h$ being captured in secondary sample $j$ of primary period $i$, given being alive and in the study area during period $i$, where $h=$ Whale 1 , Whale $2, \ldots$, Whale $129 ; j=$ June, July,..., October; and $i=1997,1998, \ldots, 2003$. Capture probability was estimated according to the highest AICcweighted model in the Bradford et al. (2006) analysis: $p(t+R e s)$, where $t=$ time varying by secondary period, Res $=$ residency (individual covariate), and $+=$ additive model.

The temporary emigration probabilities of whales $\geq 4 \mathrm{yr}$ old and $<4 \mathrm{yr}$ old were estimated as 0.168 ( $\mathrm{SE}=$ 0.0256 ) and 0.311 (SE $=0.0805)$, respectively, in the 1997 to 2003 robust design analysis (Bradford et al. 2006). These probabilities were applied to the estimates of $N_{g i}$ using Eq. (2) in order to obtain the yearly total number of individuals in each group $\left(N_{g i}^{o}\right)$. As $N_{g i}$ was derived from estimates of capture probability, the covariance between each estimate of capture probability and temporary emigration was examined in a variance-covariance matrix. Given a lack of covariance (i.e. covariance $\leq 0.1$ ) between these values, an approximation of the delta method (see Seber 1982, for a derivation of the delta method) was used to find the coefficient of variation (CV) for each revised group estimate $\left(N_{g i}^{\mathrm{o}}\right)$ :

$$
\operatorname{CV}\left(\frac{1}{\left(1-\gamma_{g}\right)} N_{g i}\right)=\sqrt{\left(\frac{\operatorname{SE}\left(\gamma_{g}\right)}{1-\left(\gamma_{g}\right)}\right)^{2}+\mathrm{CV}^{2}\left(N_{g i}\right)}
$$

The standard error (SE) and lognormal 95\% confidence intervals (CI) (see Burnham et al. 1987, for details of computing the CI) of each revised group estimate were then determined. It is important to note that the $<4$ yr old group consisted only of whales first 
sighted as calves. Thus, there is likely a positive bias in the $\geq 4$ yr old estimates of temporary emigration and $N_{g i}$ by the influence on those estimates of young whales in the dataset not first sighted as calves, particularly in the earlier years of the study period. Similarly, there is potentially a negative bias in these estimates for whales $<4$ yr old. However, the same group structure was maintained when estimating both parameters, so it is appropriate to incorporate the estimates into Eq. (2), even if the resulting group population size is not the 'true' number of individuals in that group. Further, total yearly population size $\left(N_{i}^{o}\right)$ is the parameter of interest, not the actual number of whales $\geq 4 \mathrm{yr}$ old and $<4$ yr old. Total abundance in each year was obtained by:

$$
N_{i}^{\mathrm{o}}=N_{\geq 4 \text { yr old }, i}^{\mathrm{o}}+N_{<4 \text { yr old }, i}^{\mathrm{o}}
$$

Given a lack of covariance between the 2 temporary emigration probabilities, as well as between the capture probabilities used to estimate $N_{g i}$, the variance of each total population estimate was calculated as the sum of the variances of the group estimates, permitting the determination of associated SE and lognormal $95 \%$ CI. As in Bradford et al. (2006), assumptions of the present analysis are (1) all whales possess unique markings and were correctly identified; (2) the population was closed to births, deaths, immigrants, and emigrants within each primary sampling period; (3) all western gray whales used or passed through the study area during the study period, but not necessarily in each year. In Pollock's robust design model (Pollock 1982, Kendall \& Pollock 1992, Kendall \& Nichols 1995, Kendall et al. 1995, 1997), a temporary emigration probability for the first primary sampling period cannot be estimated because there are no marked individuals outside the study area at that time. Thus, the group-varying temporary emigration estimates from the 1997 to 2003 robust design analysis correspond to the 1998 to 2003 sampling periods. In order to produce an abundance estimate for 1997, a fourth assumption of the abundance estimation is that the temporary emigration estimates are applicable to that year.

Growth rate estimation. According to Lotka's equation of unity (Lotka 1907, Cole 1954), any given set of age-specific survival and reproductive parameters can be characterized by a unique population growth rate. The form of the Lotka equation allowing for a discrete time (in this case, annual) life history representation (e.g. Goodman 1982) was used to estimate the population growth rate of western gray whales from 1997 to 2003:

$$
1=\sum_{X=1}^{W} \lambda^{-x} l_{X} m_{X}
$$

where $x$ is age class, $w$ is the maximum age class, $\lambda$ is the finite population growth rate, $l_{x}$ is the survival to age class $X$, and $m_{X}$ is the fecundity of age class $x$.
When implementing the Lotka equation, the first age class (i.e. age class 1) generally relates to young of the year at the time of birthing (i.e. age 0 individuals), such that $l_{1}=1$. As the western gray whale growth rate estimation is based predominantly on information gleaned from the Piltun feeding ground (i.e. between birthing seasons), age class 1 actually corresponds to young of the year (i.e. calves) that are approximately 6 to 8 mo of age (Weller et al. 1999). The fact that $l_{1}$ is technically unknown in this case is offset by the incorporation of apparent fecundity into the growth rate estimate. That is, the measure of fecundity is also based on observations made during the feeding season. Therefore, fecundity estimates will reflect any loss of calves between the breeding and feeding grounds, making $l_{1}=1$ an appropriate assumption for the present analysis. The specific life history parameters used in the western gray whale growth rate estimation are detailed later in this subsection.

The average longevity of western gray whales is unknown and can only be speculated for eastern gray whales (Rice \& Wolman 1971). However, the maximum age class $(w)$ incorporated into the Lotka equation does not necessarily characterize the longevity of individuals in the population, and can in fact be much larger. When average survival probabilities representing an unknown demographic are used to calculate the $l_{x}$ schedule, $w$ should be fixed at a value large enough to allow $l_{W}$ to approach zero. As the western gray whale growth rate estimation utilized an average non-calf survival probability (Bradford et al. 2006), the maximum age class was set at 150 . To illustrate the principle of this concept, summing the Lotka equation to $w=1000$ would not have changed the results of the growth rate estimation. Further, in the older scientific literature (e.g. Cole 1954), w was often alternatively represented by $\infty$.

The intrinsic growth rate of a population $(r)$ is another measure of population increase often represented in population dynamics modeling and assessment. When the annual increase all occurs within a short period of time during the year, which is the case for gray whales, the finite population growth rate $(\lambda)$ estimated by the Lotka equation most appropriately corresponds to $r$ according to the relationship (Eberhardt 1985):

$$
\lambda=1+r
$$

For comparing estimates of the finite population growth rate with the trend in the abundance estimates (a measure of $r$ ), consistency in reported growth rates was required. Therefore, results of the Lotka growth rate estimation are described in terms of $\lambda-1$.

Four life history parameters were required for the western gray whale growth rate estimation: (1) calf 
survival; (2) non-calf survival; (3) calving interval (i.e. time in years between births of consecutive calves); and (4) age at sexual maturity (ASM). The aforementioned mark-recapture calf and non-calf survival estimates $(\phi)$ (Bradford et al. 2006) were utilized to construct the $l_{x}$ schedule of the Lotka equation for age class 2 (recall that $l_{1}=1$ ) to age class $w$, where:

$$
l_{X}=\phi_{X-1} l_{X-1}
$$

Thus, the calf survival estimate became $\phi_{1}$, and the non-calf estimate $\phi_{2 \rightarrow W-1}$. Calf and non-calf survival values were selected from a beta distribution (i.e. between 0 and 1) with a mean of $0.701(\mathrm{SE}=0.0944)$ and 0.951 (SE = 0.0135), respectively (Bradford et al. 2006).

Fecundity $\left(m_{x}\right)$ is the average rate at which female young are produced each year by females, and can be calculated as:

$$
m_{X}=\frac{1}{C A} S R \phi_{X}
$$

where $C A$ is the calving interval, $S R=$ population sex ratio (assumed to be 0.5 ).

The western gray whale calving interval was determined from photo-identification records of females with calves on the Piltun feeding ground (Table 2), following the estimation method of Jones (1990) for eastern gray whales. As in Jones (1990), only females with one or more observed calving intervals contributed to the estimation. In addition to photographic sightings collected between 1997 and 2003, photo-identification records from a 1995 pilot study (Brownell et al. 1997) were included in the calculation, as these data added one observed calving interval each to the encounter histories of 2 females (Table 2).

Averaging the 14 observed calving intervals (4 yr $C A: \mathrm{n}=2 ; 3$ yr $C A: \mathrm{n}=8 ; 2$ yr $C A: \mathrm{n}=4$ ) highlighted in Table 2 would lead to a measure of apparent fecundity. However, this measure could potentially be confounded by the capture probability of one or more of the represented females. That is, a female who might have been associated with a calf during any given feeding season could have been sighted only after her calf was weaned, or potentially not observed at all, such that an observed $C A$ might actually represent 2 separate intervals. In general, such a scenario was assumed atypical given the marked seasonal site fidelity to the study area exhibited by females and their calves (Weller et al. 1999, 2002b) and the infrequency of first sighting calves during a field season after weaning has occurred ( $\mathrm{n}=5$ of 40 calves identified between 1997 and 2003). Further, suggesting that the observed calving interval represents 2 intervals would have introduced 1 yr calving intervals in 12 of the 14 cases,

Table 2. Eschrictius robustus. Annual records of known reproductive western gray whale females $(\mathrm{n}=23)$ photographically identified on the Piltun feeding ground between 1995 and 2003 (no data were collected in 1996). 1 = photographically identified. $\mathrm{C}=$ photographically identified with a calf. $0=$ not photographically identified. $\mathrm{n}=$ the number of calving intervals (gray shading)

\begin{tabular}{|c|c|c|c|c|c|c|c|c|c|c|}
\hline Whale ID & 1995 & 1996 & 1997 & 1998 & 1999 & 2000 & 2001 & 2002 & 2003 & $\mathrm{n}$ \\
\hline 005 & 0 & - & 1 & C & 1 & 1 & 1 & C & 0 & $1^{a}$ \\
\hline 007 & 1 & - & 1 & 1 & 1 & 1 & C & 0 & C & 1 \\
\hline 008 & 1 & - & 1 & 1 & 0 & 1 & 1 & 0 & $\mathrm{C}$ & 0 \\
\hline 009 & 1 & - & 1 & $\mathrm{C}$ & 1 & 1 & $\mathrm{C}$ & 1 & 1 & 1 \\
\hline 011 & 0 & - & 1 & 1 & 1 & 1 & 1 & $\mathrm{C}$ & 0 & 0 \\
\hline 015 & 0 & - & 1 & $\mathrm{C}$ & 1 & 1 & 1 & $\mathrm{C}$ & 1 & $1^{\mathrm{a}}$ \\
\hline 018 & $\mathrm{C}$ & - & 1 & $\mathrm{C}$ & 1 & 1 & $\mathrm{C}$ & 0 & $\mathrm{C}$ & 3 \\
\hline 019 & $\mathrm{C}$ & - & $\mathrm{C}$ & 1 & 1 & $\mathrm{C}$ & 1 & 1 & $\mathrm{C}$ & 3 \\
\hline 026 & 0 & - & 1 & 1 & 0 & 0 & 0 & $\mathrm{C}$ & 0 & 0 \\
\hline 030 & 1 & - & 1 & 1 & 1 & 0 & 1 & 0 & $\mathrm{C}$ & 0 \\
\hline 031 & 0 & - & $\mathrm{C}$ & 0 & 0 & 0 & 0 & 0 & 0 & 0 \\
\hline 034 & 1 & - & 1 & 1 & 1 & 1 & 1 & 1 & $\mathrm{C}$ & 0 \\
\hline 036 & 0 & - & 1 & $\mathrm{C}$ & 1 & 1 & $\mathrm{C}$ & 1 & 1 & 1 \\
\hline 038 & 1 & _- & 1 & 1 & $\mathrm{C}$ & 0 & 1 & 1 & 1 & 0 \\
\hline 040 & 0 & - & 1 & 1 & $\mathrm{C}$ & 0 & 0 & $\mathrm{C}$ & 0 & 1 \\
\hline 043 & 1 & - & 0 & 0 & 1 & 1 & 1 & $\mathrm{C}$ & 1 & 0 \\
\hline 055 & 0 & - & 0 & $\mathrm{C}$ & 1 & 1 & $\mathrm{C}$ & 1 & $\mathrm{C}$ & 2 \\
\hline 063 & 0 & - & 1 & C & 0 & 1 & 1 & 1 & 0 & 0 \\
\hline 076 & 0 & - & 0 & 0 & 1 & 1 & 1 & 1 & $\mathrm{C}$ & 0 \\
\hline 081 & 0 & - & 0 & 0 & 1 & 1 & 1 & 1 & $\mathrm{C}$ & 0 \\
\hline 087 & 0 & - & 0 & 0 & 1 & $\mathrm{C}$ & 1 & 0 & 1 & 0 \\
\hline 092 & 0 & - & 0 & 0 & 0 & 1 & $\mathrm{C}$ & 1 & 0 & 0 \\
\hline 122 & 0 & - & 0 & 0 & 0 & 0 & 0 & 0 & $\mathrm{C}$ & 0 \\
\hline
\end{tabular}
observed for each female 
and annual breeding is considered rare for this species (Jones 1990).

The remaining 2 cases are the observed 4 yr calving intervals of Whale ID 005 and Whale ID 015 (Table 2). These females both had calves in 1998 and 2002, but it is biologically plausible that one or both of them produced a calf in 2000 that survived until the feeding season. Although Whale ID 005 and Whale ID 015 were sighted in 2000, they were first observed on 12 August and 30 July of that year, respectively. Both dates are within the range of known weaning times for western gray whales (Weller et al. 1999). Further, one of the 3 calves identified in 2000 was first sighted postweaning. Therefore, suggesting that the observed $4 \mathrm{yr}$ calving intervals could in fact represent two 2 yr intervals is not an unreasonable assumption.

The goal of calculating the average western gray whale calving interval is to estimate apparent fecundity, and subsequently the current growth rate. While averaging the 10 observed intervals might underestimate apparent fecundity because of a possible capture probability influence, assuming that the observed 4 yr calving intervals represent two 2 yr intervals could overestimate apparent fecundity. That is, if Whale ID 005 or Whale ID 015 produced a calf in 2000 that did not survive until the feeding season, an overestimate of apparent fecundity (and the violation of the aforementioned $l_{1}=1$ assumption) would result. Therefore, the preferred approach was to bracket a likely range of fecundity values, and thus growth rate estimates. Consequently, a long, medium, and short estimate of calving interval was incorporated into a separate fecundity and growth rate estimation. The long calving interval estimate was the average of the 10 observed intervals; the short estimate was the average with both of the observed $4 \mathrm{yr}$ intervals representing two $2 \mathrm{yr}$ intervals $(\mathrm{n}=16)$. The medium calving interval estimate attributed two $2 \mathrm{yr}$ calving intervals to either Whale ID 005 or Whale ID 015 ( $\mathrm{n}=15$ ). The long, medium, and short calving interval values were selected from a normal distribution with a mean of $2.9(\mathrm{SE}=0.18), 2.7(\mathrm{SE}=0.16)$, and $2.5(\mathrm{SE}=0.13)$, respectively.

The ASM indicates the first age class with non-zero fecundity in the $m_{X}$ schedule. As the first age class in the Lotka equation is generally composed of age 0 individuals, $m_{\mathrm{ASM}+1}$ is the first non-zero value. Given that apparent fecundity was considered in the present growth rate estimation, the first non-zero fecundity value was set at age class ASM+1, despite the previously described 6 to 8 mo offset in the age classes. The ASM of western gray whales is unknown, but a median value of $6 \mathrm{yr}$ (range: 5 to $9 \mathrm{yr}$ ) has been estimated for eastern gray whales (Reilly 1992). Assuming that eastern and western gray whales share similar reproductive capabilities, but making no assumptions about a median value for western gray whales, values for western gray whale ASM were selected from a discrete uniform distribution of 5 to $9 \mathrm{yr}$.

According to the nature of Eq. (8), non-zero values of $m_{x}$ should be conditional on the survival of mature females. In the present analysis, the $\phi_{X}$ used to calculate these values was a non-calf, sex-aggregated estimate (i.e. based on observations of juvenile and adult whales of both sexes). While sex-specific differences in survival can not be presumed, it is likely that juvenile survival rates are lower than those of adults (Caughley 1966). Thus, there was a source of negative bias in the fecundity estimates that could not be avoided, given the available data. However, this negative bias may have been offset to some degree by a possible positive bias arising from the use of observed calving intervals and the assumption of an even sex ratio. That is, the use of observed calving intervals does not account for calving intervals that exceeded the length of the study. Also, although an even sex ratio is a common assumption in mammalian demographic studies, a male bias has been documented in biopsy samples taken from western gray whales (Weller et al. 2002b). Overall, population growth rates of long-lived animals are least sensitive to changes in fecundity rates (Goodman 1981, Taylor \& DeMaster 1993). Hence, the impact of potentially biased fecundity values on the resulting growth rate estimates was presumed to be minimal.

In order to account for the uncertainty of the input life history parameters, the 1997 to 2003 western gray whale population growth rate was estimated using a Monte Carlo simulation method (e.g. Cox \& Baybutt 1981). Values of the life history parameters were randomly selected from their associated distributions and incorporated into the Lotka equation, and a growth rate specific to that set of parameters was determined. This process was conducted a large number of times ( $n=10000)$, producing a growth rate estimate in the form of a distribution. The simulation routine was performed employing the long, medium, and short estimates of calving interval, generating a conservative, intermediate, and liberal growth rate estimate, respectively.

\section{RESULTS}

Using the robust design model and the additional Huggins' closed capture group estimator, yearly estimates of western gray whales using the study area, corresponding temporary emigration probabilities, and total population sizes for whales $\geq 4 \mathrm{yr}$ old and $<4$ yr old are displayed in Table 3 . Total abundance in 
Table 3. Eschrictius robustus. Yearly number of western gray whales identified $(n)$, estimates of individuals using the study area each year $(N)$, temporary emigration probabilities $(\gamma)$, and total population size associated with the study area ( $N^{\circ}$ for whales $\geq 4 \mathrm{yr}$ old and $<4 \mathrm{yr}$ old from 1997 to 2003. Associated SE and $95 \%$ confidence intervals (CI) are included

\begin{tabular}{|c|c|c|c|c|c|c|c|c|c|}
\hline Year & $\mathrm{n}$ & $N$ & $\mathrm{SE}$ & $95 \% \mathrm{CI}^{\mathrm{a}}$ & $\gamma$ & $\mathrm{SE}$ & $N^{\circ}$ & $\mathrm{SE}$ & $95 \% \mathrm{CI}$ \\
\hline \multicolumn{10}{|c|}{ Whales $\geq 4$ yr } \\
\hline 1997 & 45 & 51 & 3.9 & $47-64$ & 0.168 & 0.0256 & 61 & 5.1 & $52-72$ \\
\hline 1998 & 45 & 50 & 3.3 & $47-61$ & 0.168 & 0.0256 & 60 & 4.4 & $52-69$ \\
\hline 1999 & 62 & 63 & 1.4 & $62-69$ & 0.168 & 0.0256 & 76 & 2.9 & $71-82$ \\
\hline 2000 & 51 & 55 & 3.2 & $52-67$ & 0.168 & 0.0256 & 66 & 4.4 & $58-76$ \\
\hline 2001 & 63 & 65 & 1.5 & $63-70$ & 0.168 & 0.0256 & 78 & 3.0 & $72-84$ \\
\hline 2002 & 62 & 64 & 1.9 & $63-72$ & 0.168 & 0.0256 & 77 & 3.3 & $71-84$ \\
\hline 2003 & 54 & 56 & 1.9 & $55-63$ & 0.168 & 0.0256 & 68 & 3.1 & $62-74$ \\
\hline \multicolumn{10}{|c|}{ Whales < $4 \mathrm{yr}$} \\
\hline 1997 & 2 & 2 & 0.2 & $2-3$ & 0.311 & 0.0805 & 3 & 0.4 & $2-4$ \\
\hline 1998 & 9 & 10 & 1.0 & $9-14$ & 0.311 & 0.0805 & 14 & 2.2 & $11-19$ \\
\hline 1999 & 7 & 7 & 0.1 & $7-8$ & 0.311 & 0.0805 & 10 & 1.2 & $8-13$ \\
\hline 2000 & 7 & 7 & 0.7 & $7-11$ & 0.311 & 0.0805 & 11 & 1.6 & $8-14$ \\
\hline 2001 & 9 & 9 & 0.2 & $9-11$ & 0.311 & 0.0805 & 13 & 1.6 & $10-17$ \\
\hline 2002 & 14 & 14 & 0.3 & $14-16$ & 0.311 & 0.0805 & 20 & 2.4 & $16-26$ \\
\hline 2003 & 21 & 21 & 0.6 & $21-25$ & 0.311 & 0.0805 & 31 & 3.7 & $25-39$ \\
\hline
\end{tabular}

Table 4. Eschrictius robustus. Yearly number of western gray whales identified $(n)$, estimates of individuals using the study area each year $(N)$, and total population size associated with the study area $\left(N^{\circ}\right)$ from 1997 to 2003. Associated $\mathrm{SE}$ and $95 \%$ confidence intervals (CI) are included

\begin{tabular}{|c|c|c|c|c|c|c|c|}
\hline Year & $\mathrm{n}$ & $N$ & $\mathrm{SE}$ & $95 \% \mathrm{Cl}^{\mathrm{a}}$ & $N^{\circ}$ & $\mathrm{SE}$ & $95 \% \mathrm{CI}$ \\
\hline 1997 & 47 & 53 & 3.9 & $49-66$ & 64 & 5.1 & $55-75$ \\
\hline 1998 & 54 & 60 & 3.5 & $56-71$ & $75^{\mathrm{b}}$ & 4.9 & $66-85$ \\
\hline 1999 & 69 & 70 & 1.4 & $69-76$ & 86 & 3.1 & $80-93$ \\
\hline 2000 & 58 & $63^{\mathrm{b}}$ & 3.3 & $59-74$ & 77 & 4.7 & $68-87$ \\
\hline 2001 & 72 & 74 & 1.5 & $72-79$ & 91 & 3.4 & $84-98$ \\
\hline 2002 & 76 & 78 & 2.0 & $77-86$ & $98^{\mathrm{b}}$ & 4.1 & $90-106$ \\
\hline 2003 & 75 & $78^{\mathrm{b}}$ & 2.0 & $76-85$ & 99 & 4.9 & 90-109 \\
\hline \multicolumn{8}{|c|}{$\begin{array}{l}\text { "As in Program Mark (White \& Burnham 1999), these } 95 \% \text { CIs were } \\
\text { computed by taking } n \text { into account in a slight variation of the method used } \\
\text { for the total abundance estimates (see 'Materials and methods: Abundance } \\
\text { estimation') } \\
\text { b Value exceeds the sum of the corresponding numbers in Table } 3 \text { due to } \\
\text { round-off error }\end{array}$} \\
\hline
\end{tabular}

an exponential model to the estimated number of whales associated with the Piltun feeding ground over the study period $\left(N^{\circ}\right)$, an overall increase was detected (Fig. 2), at a rate of 0.068 ( $\mathrm{SE}=0.0128,95 \% \mathrm{CI}=0.035$ to 0.101 ).

The conservative, intermediate, and liberal 1997 to 2003 population growth rates were estimated as 0.025 (SD = 0.0164 , 5th to 95th percentiles = -0.004 to 0.050$), 0.028$ ( $\mathrm{SD}=0.0166$, 5 th to 95th percentiles $=-0.001$ to 0.054 ), and $0.032(\mathrm{SD}=0.0167,5$ th to 95th percentiles $=0.002$ to 0.057), respectively (Fig. 3). As expected, the sequence of these estimates reflects the incorporation of the low, medium, and high fecundity values, respectively, with higher fecundity estimates resulting in increased growth rates. The growth rate estimates suggest that the western gray whale population was increasing during the observation period. However, in each case, the left tails of the distribution indicate that some combinations of the life history parameters produced a negative growth rate (Fig. 3).

\section{DISCUSSION}

\section{Application of estimates}

Although all of the abundance estimation and most of the population growth rate estimation are based on data collected on the Piltun feeding ground, this area is considered to be used by most, if not all, individuals in the western gray whale population at some point in their life history. This idea is supported by several lines of evidence: (1) aerial and ship-based marine mammal surveys of the

each year, resulting from summing the group-specific estimates (Eq. 4), is shown in Table 4 and Fig. 2. Estimates of the number of whales using the study area in each year $(N)$ are also included in Table 4 . These values are identical to estimates that were calculated using Huggins' closed capture estimator and the $p(t+R e s)$ capture probability model within the 1997 to 2003 robust design model of Bradford et al. (2006), which did not produce the group-specific estimates needed to account for temporary emigration. By fitting
Okhotsk Sea in recent decades found the only major tun region (Blokhin et al. 1985, Berzin et al. 1988, 1990, 1991, Blokhin 1996, Miyashita 1997, Miyashita et al. 2001); (2) usable photographic sightings of whales in other parts of the Okhotsk Sea have been matched to individuals that regularly use the Piltun feeding ground (Weller et al. 2002a, 2003); and (3) the Piltun feeding ground is the only area where post-parturient females with nursing calves have been observed and consistent concentrations of gray whales in the Pil- 


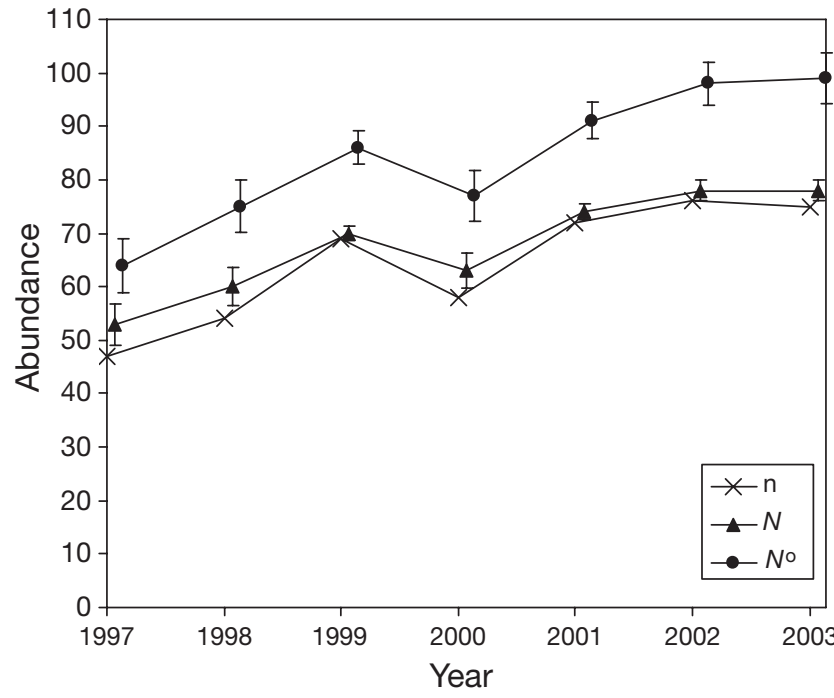

Fig. 2. Eschrichtius robustus. Yearly number of western gray whales identified $(n)$, estimates $( \pm$ SE) of individuals using the study area in each year $(N)$, and total population size $( \pm \mathrm{SE})$ associated with the study area $\left(N^{\circ}\right)$ from 1997 to 2003

(Weller et al. 2002b). Thus, the western gray whale population is strongly linked to the Piltun feeding ground, even though individuals may use other areas for all or part of a feeding season. This link suggests that the estimates reported herein can be interpreted at the population level, even though they are based on data collected in a single region within a larger range.

\section{Abundance estimates}

The estimates presented here provide the first published quantitative measure of western gray whale abundance. In addition, these estimates substantiate other indications that the western gray whale population is small. These indicators are (1) minimal numbers of western gray whales observed during the aforementioned aerial and ship-based Okhotsk Sea surveys (Blokhin et al. 1985, Berzin et al. 1988, 1990, 1991, Blokhin 1996, Miyashita 1997, Miyashita et al. 2001); (2) extreme rarity of western gray whale sightings in other parts of their range (i.e. Japan, North and South Korea, and China) (Wang 1978, 1984, Furuta 1984, Kato \& Tokuhiro 1997, Zhu 1998, Kato \& Kasuya 2002, Yamada et al. 2002); and (3) low direct counts and nearly stable rates of discovery of individual western gray whales on the Piltun feeding ground (Weller et al. 2002b). Further, these estimates are consistent in magnitude with an estimate of predicted current western gray whale population size resulting from a recent preliminary individual-based modeling assessment using the same data as the mark-recapture analyses detailed
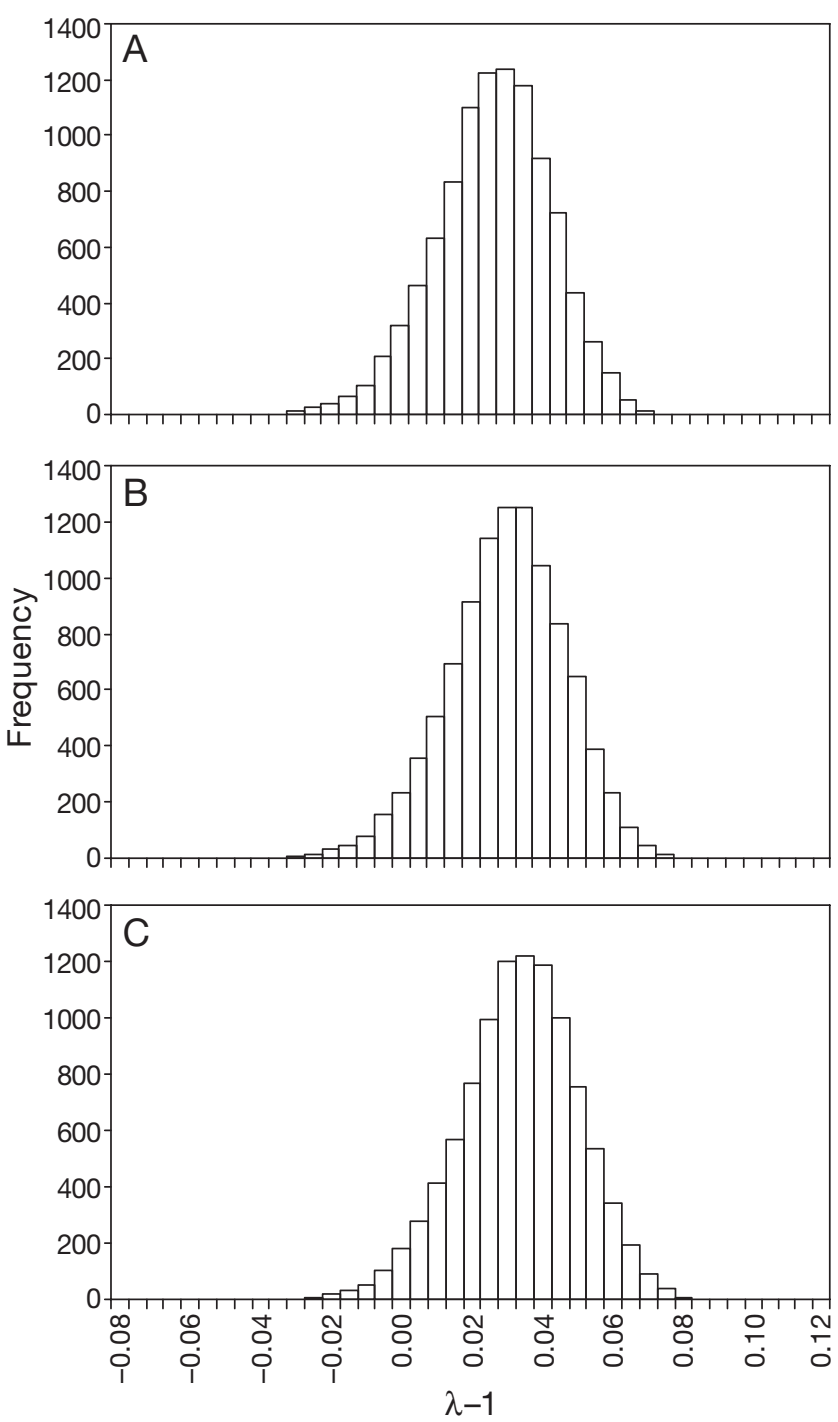

Fig. 3. Eschrichtius robustus. Histogram of values for the (A) conservative, (B) intermediate, and (C) liberal estimates of 1997 to 2003 western gray whale population growth rate $(\lambda-1)$

here, but also including data from 2004 through 2006 (Cooke et al. 2007).

The computation of the present abundance estimates and the associated assumptions warrant discussion. Given the extensive photo-identification survey effort during each field season, such that the rate of encountering different whales plateaued each season (e.g. Weller et al. 1999), combined with the capture probability estimates that incorporate the residency patterns of individuals (Bradford et al. 2006), the resulting closed capture estimates of individuals using the study area each year were not expected to be much higher than the number of whales identified (Table 4, Fig. 2). Further, as photo-identification results have indicated that individuals can be away from the study area for all of a field season (Weller et al. 1999, 2002a,b, 2003), 
these whales would not have been included in the basic closed capture estimates, even if an estimator other than Huggins' had been employed. While an open mark-recapture model would likely have better accounted for these individuals, the ability to model heterogeneity in capture probability and to estimate the population size in each primary sampling period would have been lost (Kendall \& Pollock 1992). Therefore, the method utilized here, which applied temporary emigration probabilities estimated by the robust design model, was a necessary and appropriate means of obtaining total western gray whale population size.

Regarding the 4 assumptions of the abundance estimation, the first 3 overlap with the analysis of Bradford et al. (2006) and are addressed in detail there. In summary, a violation of the markings assumption is considered unlikely, given the reliability and uniqueness of gray whale pigmentation patterns (e.g. Darling 1984, Weller et al. 1999), as well as the careful evaluation of the western gray whale photo-identification dataset (Weller et al. 1999). As for population closure during each primary sampling period, births and deaths did not occur within the field seasons, although at least some whales did spend time away from the study area (Weller et al. 1999, 2002a,b, 2003). However, as aforementioned, random movement in and out of a study does not bias closed capture parameter estimates, but does reduce their precision (Kendall 1999). The third assumption relating to the presence of all western gray whales in the study area at some point during the study period was addressed in 'Discussion: Application of estimates'. That is, the weight of evidence supports a strong association between the western gray whale population and the Piltun feeding ground, allowing the estimates reported here to be considered population level estimates. If there is a portion of the western gray whale population that never uses or passes through the study area, then these individuals would not be accounted for in the present estimates. However, the idea that such a subset exists, particularly one representing a substantial number of whales, is unlikely. The fourth assumption was made specifically for the current analysis and pertains to the production of a 1997 abundance estimate based on temporary emigration probabilities that technically correspond to 1998 to 2003 primary sampling periods. The assumption that these probabilities would have been the same in 1997 is not unreasonable, although its appropriateness cannot be confirmed. For other reasons (see following paragraph), it is likely that the first estimates in the abundance trajectory are negatively biased. Thus, the importance of reconciling possible violations to this last assumption is minimized.

A $7 \%$ increase was detected in the estimated number of western gray whales associated with the Piltun feeding ground from 1997 to 2003 (Fig. 2). This rate should not be interpreted solely as population growth, as it also represents an increase in the number of whales using the study area. As the temporary emigration probabilities in the robust design model of Bradford et al. (2006) are conditional on the first detection of an individual, the analytical framework does not account for whales that were temporarily emigrating when the photo-identification study began. That is, it is highly possible that there were individuals not using the Piltun feeding ground in the first years of the study period that returned to the study area in later years. This effect would have produced an increase in the total population size associated with the study area, but this increase would not necessarily reflect actual population growth. In other words, previously unidentified temporary emigrants revisiting the Piltun feeding ground over the course of the study period could have contributed to the observed trend, with the implication that the last estimates in the abundance trajectory more accurately represent actual western gray whale population size than the first, which are negatively biased. In that regard, if an evaluation of the trend is restricted to the last 3 estimates, a rate of $4 \%$ is observed (Fig. 2), which is more closely aligned with the population growth rate estimated from the life history data (Fig. 3). Another feature of the trend in the abundance trajectory is that it is based on the application of group-varying temporary emigration estimates that were constant throughout the study period, as these estimates were a component of the highest AICCweighted model in the Bradford et al. (2006) analysis. The actual temporary emigration probabilities could have been time-varying, but the data could not support the estimation of additional parameters (Bradford et al. 2006). However, if time-varying temporary emigration probabilities had been applied, the resulting trend in the series of abundance estimates would likely have changed.

\section{Growth rate estimates}

When life history information was used to estimate the population growth rate of western gray whales, the conservative, intermediate, and liberal growth rate estimates were each relatively lower than the rate of increase suggested by the full series of abundance estimates (Figs. 2 \& 3). However, it is worth mentioning that when the descriptive statistics of the growth rate estimates are compared to those of the abundance trend, there is statistical overlap. Although the range encompassed by the 3 growth rate estimates was relatively narrow, the exact value of the estimated growth rate depended on the fecundity value that was incor- 
porated, with shorter calving interval estimates leading to slightly elevated growth rates. Regarding the estimates of western gray whale calving interval, biological and observational data collected during the recovery of eastern gray whales indicated that this population predominantly adhered to a 2 yr calving interval (Rice \& Wolman 1971, Blokhin 1984, Jones 1990). Evidence exists that, at least during the late 1980s, pregnancy rates of eastern gray whales have declined (Reilly 1992). Compensatory density dependent mechanisms would suggest that lower pregnancy rates (i.e. prolonged calving intervals) would be attributed to the population reaching higher densities (e.g. Fowler 1981). If the reproductive potentials of eastern and western gray whales are comparable, then a maximized reproductive output based on a 2 yr calving interval would be expected for the low-density western gray whale population. However, the low, medium, and high western gray whale fecundity values used in the growth rate estimation were all based primarily on 3 yr calving intervals (Table 2). The reason for the prolongation of western gray whale calving intervals is unknown, although nutritional stress has been hypothesized (Brownell \& Weller 2002).

Despite the estimates of relatively longer calving interval, as well as the estimates of relatively reduced calf survival (Bradford et al. 2006), the 1997 to 2003 population growth rate estimates imply that the population was increasing during that time (Fig. 2). However, the calculated growth rates are comparatively lower than estimates from other depleted populations of baleen whales. Best (1993) summarized the growth rates of 9 severely depleted baleen whale populations (i.e. estimated to be less than $10 \%$ of their original population size at one time), including 1 bowhead Balaena mysticetus, 3 right Eubalaena australis, one gray (eastern), one blue Balaenoptera musculus, and 3 humpback Megaptera novaengliae whale populations. These growth rate estimates ranged from 0.031 to 0.144 , but were not necessarily measured when the populations were at their lowest levels. Depletion levels were known for 5 of the 9 populations and demonstrated that higher growth rates corresponded to more depleted populations (Best 1993). Yet, the 1997 to 2003 growth rates calculated for the severely depleted western gray whale population are markedly lower than the growth rate estimates of the 3 most depleted populations discussed in Best (1993). However, drawing conclusions from this contrast is potentially imprudent, as the growth rate values of these 3 populations (i.e. one right and 2 humpback whale populations) have large or unknown associated errors (Best 1993).

A potentially more meaningful comparison can be made between the 2 gray whale populations. The trajectory of abundance estimates for eastern gray whales showed an annual rate of increase of 0.032 ( $\mathrm{SE}=0.0055)$ during the period when the population doubled from about 10000 to 20000 whales, while maintaining an aboriginal harvest averaging approximately 175 whales per year (Reilly 1992). Thus, estimates of their maximum net recruitment have ranged from 0.05 to 0.07 in stock assessments (e.g. Wade 2002). The small size of the western gray whale population implies that they could currently be growing at their maximum net recruitment rate. Yet, the present western gray whale population growth rate estimates are essentially half in value of the maximum net recruitment rates attributed to eastern gray whales. However, given that the 1997 to 2003 western gray whale population growth rate estimates could include the effect of possible anthropogenic mortality, such as entrapment in Japanese fishing gear (IISG 2006), these values may be lower than the actual biological maximum growth rate of the population.

Accounting for uncertainty in the western gray whale life history parameters revealed that some combinations of these values resulted in a negative growth rate (Fig. 3). A population exhibiting a negative population growth rate is doomed to extinction, unless anthropogenic factors contributing to the population decline can be identified and mitigated. Thus, conservation plans for western gray whales should reflect not only the depleted status of the population, but also the possibility that the population is currently declining. Future monitoring will allow for the refined estimation of the life history parameters, which is needed to further investigate the possibility that the population growth rate is not at a replacement level.

\section{CONCLUSION}

Although the population abundance and growth rate values reported here are based on observations of western gray whales on their primary feeding ground off northeastern Sakhalin Island, these estimates likely extend to the population as a whole. If such is the case, then the western gray whale population numbered around 100 individuals and was increasing at a rate of approximately $3 \%$ as of 2003 . The estimates are of importance in 2 main respects. First, they demonstrate the value of the Russia-US western gray whale research program, which was able to make fundamental and relatively precise inference about an unknown population in a rather short period of time. Therefore, the monitoring study should continue so that potential changes in these estimates can be detected. Second, they emphasize the critically endangered status of western gray whales and enhance existing concern 
about the viability of the population. Small populations are already at risk from inherent factors, but current anthropogenic threats could compound this risk. Among these threats for western gray whales is disturbance associated with intensive oil and gas development on the Piltun feeding ground and surrounding areas (Reeves et al. 2005). Additionally, entrapment in coastal set nets off Japan is an ongoing source of western gray whale mortality, with 4 female whales known to have been fatally entrapped between 2005 and 2007 (IISG 2006, Anonymous 2007). Mitigating these human-caused threats is essential if the small, slow-growing western gray whale population is to persist.

Acknowledgements. We thank the many individuals who have provided assistance to us over the years, in particular the tireless efforts of S. Blokhin, Y. Ivashchenko, H. W. Kim, A. Lang, S. Rickards, G. A. Tsidulko, and B. Würsig. Support and funding for this project were provided (in alphabetical order) by Exxon Neftegas Limited, the International Fund for Animal Welfare, the International Whaling Commission, the Marine Mammal Commission, the Marine Mammal Research Program at Texas A\&M University at Galveston, the National Fish and Wildlife Foundation, the National Marine Fisheries Service, Ocean Park Conservation Foundation, Sakhalin Energy Investment Company, the School of Aquatic and Fishery Sciences at the University of Washington, the US Environmental Protection Agency, and the Washington Cooperative Fish and Wildlife Research Unit. This project (1995 to 2003) was conducted as part of the Marine Mammal Project under Area V: Protection of Nature and the Organization of Reserves within the US-Russia Agreement on Cooperation in the Field of Environmental Protection.

\section{LITERATURE CITED}

Akaike H (1973) Information theory and an extension of the maximum likelihood principle. In: Petrov BN, Csaki F (eds) Second International Symposium on Information Theory. Akademiai Kiado, Budapest, p 267-281

Anonymous (2007) Japanese nets threaten grey whale's survival. Nature 445:577

Berzin AA (1990) Gray whales of the Okhotsk-Korean population in the Sea of Okhotsk. Paper SC/A90/G28 presented to the International Whaling Commission Scientific Committee. Available from IWC Secretariat, www. iwcoffice.org/publications/pubmain.htm

Berzin AA, Vladimirov VL, Doroshenko NV (1988) Results of aerial surveys to study the distribution and abundance of cetaceans in the coastal waters of the Sea of Okhotsk in 1986-1987. In: Chernysheva NS (ed) Nauchno-issledovatel'skie ra'boty po morskim mlekopitayushchim severnoi chasti Tikhogo okeana v 1986-1987. All-Union Scientific Research Institute of Fisheries and Oceanography (VNIRO), Moscow, p 18-25 (in Russian)

Berzin AA, Vladimirov VL, Doroshenko NV (1990) Aerial surveys to determine the distribution and number of polar gray whales and beluga whales in the Sea of Okhotsk in 1985-1989. Izvestiya Tikhookeanskogo Nauchno-issledovatel'skogo Instituta Rybnogo Khozyaistva I Okeanografii (TINRO) 112:51-60 (in Russian)

Berzin AA, Vladimirov VL, Doroshenko NV (1991) Results of aerial surveys to study the distribution and abundance of whales in the Sea of Okhotsk in 1988-1990. In: Popov LA (ed) Nauchno-issledovatel'skie ra'boty po morskim mlekopitayushchim severnoi chasti Tikhogo okeana v 1989-1990. All-Union Scientific Research Institute of Fisheries and Oceanography (VNIRO), Moscow, p 6-17 (in Russian)

Best PB (1993) Increase rates in severely depleted stocks of baleen whales. ICES J Mar Sci 50:169-186

Blokhin SA (1984) Investigations of gray whales taken in the Chukchi coastal waters, USSR. In: Jones ML, Swartz SL, Leatherwood S (eds) The gray whale Eschrichtius robustus. Academic Press, Orlando, FL, p 487-509

Blokhin SA (1996) Distribution, abundance and behavior of gray whales (Eschrichtius robustus) of American and Asian populations in regions of their summer location nearshore of the Far East. Izvestiya Tikhookeanskogo Nauchno-issledovatel'skogo Rybokhozyaistvennogo Tsentra 121:36-53 (in Russian)

Blokhin SA, Maminov MK, Kosygin GM (1985) On the Korean-Okhotsk population of gray whales. Rep Int Whal Comm 35:375-376

Blokhin SA, Yazvenko SB, Doroshenko NV (2004) Distribution, abundance, and certain behavioral traits of the Korean-Okhotsk population of gray whales (Eschrichtius robustus) off the northeastern Sakhalin coast in the summer and fall of 2003 (based on aerial survey data from an An-28 airplane). Paper SC/56/BRG48 presented to the International Whaling Commission Scientific Committee. Available from IWC Secretariat, www.iwcoffice.org/ publications/pubmain.htm

> Bowen SL (1974) Probable extinction of the Korean stock of gray whale (Eschrichtius robustus). J Mammal 55:208-209

Bradford AL, Wade PR, Weller DW, Burdin AM and others (2006) Survival estimates of western gray whales Eschrichtius robustus incorporating individual heterogeneity and temporary emigration. Mar Ecol Prog Ser 315:293-307

> Brownell RL Jr, Chun C (1977) Probable existence of the Korean stock of the gray whale (Eschrichtius robustus). J Mammal 58:237-239

Brownell RL Jr, Weller DW (2002) Prolonged calving intervals in western gray whales: nutritional stress and pregnancy. Paper SC/54/BRG12 presented to the International Whaling Commission Scientific Committee. Available from IWC Secretariat, www.iwcoffice.org/ publications/pubmain.htm

Brownell RL Jr, Blokhin SA, Burdin AM, Berzin AA, Le Duc RG, Pitman RL, Minakuchi H (1997) Observations on Okhotsk-Korean gray whales on their feeding grounds off Sakhalin Island. Rep Int Whal Comm 47:161-162

Buckland ST (1990) Estimation of survival rates from sightings of individually identifiable whales. Rep Int Whal Comm (Spec Iss 12):149-153

Burnham KP, Anderson DR, White GC, Brownie C, Pollock KH (1987) Design and analysis methods for fish survival experiments based on release-recapture. Am Fish Soc Monogr 5:1-437

> Caughley G (1966) Mortality patterns in mammals. Ecology 47:906-918

Clapham PJ, Young SB, Brownell RL Jr (1999) Baleen whales: conservation issues and the status of the most endangered populations. Mammal Rev 29:37-60

Cole LC (1954) The population consequences of life history phenomena. Q Rev Biol 29:103-137

Cooke JG, Weller DW, Bradford AL, Burdin AM, Brownell RL Jr (2007) Population assessment of western gray whales in 2007. Paper SC/59/BRG41 presented to the International Whaling Commission Scientific Committee. Available 
from IWC Secretariat, www.iwcoffice.org/publications/ pubmain.htm

Cormack RM (1964) Estimates of survival from the sighting of marked animals. Biometrika 51:429-438

> Cox DC, Baybutt P (1981) Methods for uncertainty analysis: a comparative survey. Risk Anal 1:251-258

Darling JD (1984) Gray whales off Vancouver Island, British Columbia. In: Jones ML, Swartz SL, Leatherwood S (eds) The gray whale Eschrichtius robustus. Academic Press, Orlando, FL, p 265-280

Eberhardt LL (1985) Assessing the dynamics of wild populations. J Wildl Manag 49:997-1012

Fowler CW (1981) Comparative population dynamics in large mammals. In: Fowler CW, Smith TG (eds) Dynamics of large mammal populations. John Wiley \& Sons, New York, p $437-455$

Furuta M (1984) Note on a gray whale found in the Ise Bay on the Pacific coast of Japan. Sci Rep Whales Res Inst Tokyo 35:195-197

Goodman D (1981) Life history analysis of large mammals. In: Fowler CW, Smith TG (eds) Dynamics of large mammal populations. John Wiley \& Sons, New York, p 415-436

$>$ Goodman D (1982) Optimal life histories, optimal notation, and the value of reproductive value. Am Nat 119:803-823

Hammond PS (1986) Estimating the size of naturally marked whale populations using capture-recapture techniques. Rep Int Whal Comm (Spec Iss 8):253-282

Hammond PS, Mizroch SA, Donovan GP (eds) (1990) Individual recognition of cetaceans: use of photo-identification and other techniques to estimate population parameters. Rep Int Whaling Comm (Spec Iss 12)

Hilton-Taylor C (2000) 2000 IUCN Red List of Threatened Species. IUCN/SSC, Gland and Cambridge

Huggins RM (1989) On the statistical analysis of capture experiments. Biometrika 76:133-140

Huggins RM (1991) Some practical aspects of a conditional likelihood approach to capture experiments. Biometrics 47:725-732

Hurvich CM, Tsai CL (1989) Regression and time series model selection in small samples. Biometrika 76:297-307

IISG (2006) Report of the Interim Independent Scientists Group (IISG) on mitigation measures to protect western gray whales during Sakhalin II construction operations in 2006. IUCN, Gland and Cambridge. Available at: http:// cms.iucn.org/wgwap/publications_and_reports/index.cfm

Jolly GM (1965) Explicit estimates from capture-recapture data with both death and immigration-stochastic model. Biometrika 52:225-247

Jones ML (1990) The reproductive cycle in gray whales based on photographic resightings of females on the breeding grounds from 1977-82. Rep Int Whal Comm (Spec Iss 12): $177-182$

Kato H, Kasuya T (2002) Some analyses on the modern whaling catch history of the western North Pacific stock of gray whales (Eschrichtius robustus), with special reference to the Ulsan whaling ground. J Cetacean Res Manag 4:277-282

Kato H, Tokuhiro Y (1997) A sighting of gray whales off Kochi, southwest Japan in July 1997, with some notes on its possible migration in adjacent waters of Japan. Paper SC/49/AS17 presented to the International Whaling Commission Scientific Committee. Available from IWC Secretariat, www.iwcoffice.org/publications/ pubmain.htm

Kendall WL (1999) Robustness of closed capture-recapture methods to violations of the closure assumption. Ecology 80:2517-2525
Kendall WL, Nichols JD (1995) On the use of secondary capture-recapture samples to estimate temporary emigration and breeding proportions. J Appl Stat 22:751-762

Kendall WL, Pollock KH (1992) The robust design in capturerecapture studies: a review and evaluation by Monte Carlo simulation. In: McCullough DR, Barrett RH (eds) Wildlife 2001: populations. Elsevier Applied Science, New York, p 31-43

Kendall WL, Pollock KH, Brownie C (1995) A likelihoodbased approach to capture-recapture estimation of demographic parameters under the robust design. Biometrics 51:293-308

Kendall WL, Nichols JD, Hines JE (1997) Estimating temporary emigration using capture-recapture data with Pollock's robust design. Ecology 78:563-578

LeDuc RG, Weller DW, Hyde J, Burdin AM and others (2002) Genetic differences between western and eastern gray whales (Eschrichtius robustus). J Cetacean Res Manag 4: $1-5$

Lotka AJ (1907) Relation between birth rates and death rates. Science 26:21-22

Miyashita T (1997) Distribution of whales in the Sea of Okhotsk, results of the recent sighting cruises. IBI Reports $7: 21-28$

Miyashita T, Nishiwaki S, Vladimirov VA, Doroshenko NV (2001) Cruise report on the minke whale sighting surveys in the Sea of Okhotsk, 2000. Paper SC/53/RMP5 presented to the International Whaling Commission Scientific Committee. Available from IWC Secretariat, www.iwcoffice. org/publications/pubmain.htm

Omura H (1988) Distribution and migration of the western Pacific stock of the gray whale. Sci Rep Whales Res Inst 39:1-9

Pike GC (1962) Migration and feeding of the gray whale (Eschrichtius gibbosus). J Fish Res Board Can 19: 815-838

Pollock KH (1982) A capture-recapture design robust to unequal probability of capture. J Wildl Manag 46: 752-757

Reeves RR, Brownell RL Jr, Burdin AM, Cooke JC and others (2005) Report of the Independent Scientific Review Panel on the impacts of Sakhalin II Phase 2 on western North Pacific gray whales and related biodiversity. IUCN, Gland and Cambridge. Also available at: http://cms.iucn.org/ wgwap/publications_and_reports/index.cfm

Reilly SB (1992) Population biology and status of eastern Pacific gray whales: recent developments. In: McCullough DR, Barrett RH (eds) Wildlife 2001: populations. Elsevier Applied Science, New York, p 1062-1074

Rice DW, Wolman AA (1971) The life history and ecology of the gray whale (Eschrichtius robustus). Spec Publ Am SocMammal 3:1-142

Rugh DJ, Hobbs RC, Lerczak JA, Breiwick JM (2005) Estimates of abundance of the eastern North Pacific stock of gray whales (Eschrichtius robustus) 1997-2002. J Cetacean Res Manag 7:1-12

> Seber GAF (1965) A note on the multiple-recapture census. Biometrika 52:249-259

Seber GAF (1982) The estimation of animal abundance and related parameters, 2nd edn. Macmillan, New York

> Taylor BL, DeMaster DP (1993) Implications of non-linear density dependence. Mar Mamm Sci 9:360-371

Wade PR (2002) A Bayesian stock assessment of the eastern Pacific gray whale using abundance and harvest data from 1967-1996. J Cetacean Res Manag 4:85-98

Wang P (1978) Studies on the baleen whales in the Yellow Sea. Acta Zool Sin 24:269-277 (in Chinese) 
Wang P (1984) Distribution of the gray whale (Eschrichtius robustus) off the coast of China. Acta Theriol Sin 4:21-26 (in Chinese)

Weller DW, Würsig B, Bradford AL, Burdin AM, Blokhin SA, Minakuchi H, Brownell RL Jr (1999) Gray whales (Eschrichtius robustus) off Sakhalin Island, Russia: seasonal and annual patterns of occurrence. Mar Mamm Sci 15:1208-1227

Weller DW, Bradford AL, Burdin AM, Miyashita T and others (2002a) Photographic recaptures of western gray whales in the Okhotsk Sea. Paper SC/54/BRG13 presented to the International Whaling Commission Scientific Committee. Available from IWC Secretariat, www.iwcoffice.org/ publications/pubmain.htm

Weller DW, Burdin AM, Würsig B, Taylor BL, Brownell RL Jr (2002b) The western gray whale: a review of past exploitation, current status, and potential threats. J Cetacean Res Manag 4:7-12

Weller DW, Reeve SH, Burdin AM, Würsig B, Brownell RL Jr (2002c) A note on the spatial distribution of western gray whales (Eschrichtius robustus) off Sakhalin Island, Russia in 1998. J Cetacean Res Manag 4:13-17

Editorial responsibility: David Hodgson,

University of Exeter, Cornwall Campus, UK
Weller DW, Burdin AM, Ivashchenko YV, Tsidulko GA, Bradford AL, Brownell RL Jr (2003) Summer sightings of western gray whales in the Okhotsk and western Bering Seas. Paper SC/55/BRG9 presented to the International Whaling Commission Scientific Committee. Available from IWC Secretariat, www.iwcoffice.org/publications/ pubmain.htm

White GC, Burnham KP (1999) Program MARK: survival estimation from populations of marked animals. Bird Study (Suppl 46):120-138

Yamada TK, Uni Y, Ishikawa H (2002) Recent gray whale strandings and sightings around Japan. Paper SC/ 02/WGW08 presented to the International Whaling Commission Scientific Committee. Available from IWC Secretariat, www.iwcoffice.org/publications/pubmain. htm

Zhu Q (1998) Strandings and sightings of the western Pacific stock of the gray whale Eschrichtius robustus in Chinese coastal waters. Paper SC/50/AS5 presented to the International Whaling Commission Scientific Committee. Available from IWC Secretariat, www.iwcoffice.org/ publications/pubmain.htm

Submitted: November 9, 2007; Accepted: May 21, 2008

Proofs received from author(s): August 28, 2008 